Research Article

\title{
Beyond National Religiosity:
}

The Pericope of 1 Kings 3:3-14 and Leadership Challenges in Nigeria

\section{Favour Uroko}

${ }^{1}$ University of Nigeria, Nigeria.

Article History

Received:

01.12 .2020

Revised:

15.01 .2021

Accepted:

02.02 .2021

*Corresponding Author:

Favour Uroko

Email:

favour.uroko@unn.edu.ng

This is an open access article, licensed under: $\mathrm{CC}-\mathrm{BY}-\mathrm{SA}$

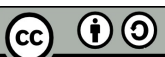

Abstract: Literature on leadership in Nigeria from the perspective of 1 Kings 3 is hard to find. In the pericope, Solomon was the successor to David in leadership. Solomon kept to the promises and good plans of his predecessor. The pericope shows the roles of godfathers in political leadership. This narrative is of great importance to Nigeria's leadership challenges in the political arena. This article examines 1 Kings 3:3-14 and its relevance to the leadership challenges in Nigeria. Nigeria is a country where leaders blackmail their predecessors and surround themselves with sycophants and godfathers. Over the years literature has focused on Nigeria's leadership challenges from the political, sociological and psychological angles. This study provides a theological response to Nigeria's leadership challenges.

Keywords: 1 Kings 3:3-14, Corruption, Leadership, Solomon. 


\section{Introduction}

1 Kings 3:3-14 is a narrative about Solomon, the son of David. Solomon took over from his father as the King of Israel. His father David worked perfectly as a good leader. When Solomon took over, he followed the good footprints of his father, David. Thus, he loved the Lord. Furthermore, Solomon associated himself with the political and religious environment of his predecessor. This was to ensure that he strived in his leadership, just like David did. The Lord advised Solomon to ensure he continued to follow the leadership style of David. The researcher believes that 1 Kings 3:3-14 will speak anew to the Nigerian situation.

In June 2018, Nigeria became the poverty capital of the world. An estimated 87 million Nigerians live on less than $\$ 1.90$ a day [1]. Poverty in Nigeria is necessitated by high-level quagmire in Nigeria's leadership. Achebe was part of those persons who saw this anomaly and he concluded, "the trouble with Nigeria is simply and squarely a failure of leadership" [2]. Leaders make very nice promises during campaigns but abandon them after they may have won the elections. Most Nigerian leaders in Nigeria paint their predecessor as corrupt, myopic, and inefficient [3]. Furthermore, Nigerian leaders keep to the dictates of their godfathers, which have aided their poor performance in government. Leaders cannot execute any important project without the opinion of the godfathers which has affected the socio-economic development of the state [4]. They surround themselves with sycophants and receive bad pieces of advice from them. These are the problem of leadership in Nigeria at the federal, state and local government levels.

Scholars have written a lot about leadership in Nigeria. Anetoh et al [5] assert that bad leadership in Nigeria has resulted in insecurity, unemployment, bad economy as well as the search for a better opportunity outside among others. The corrupt and insensitive leaders that have paraded themselves on the Nigerian political scene since independence is not only the reason for the massive retrogression that has tumbled down on

The Nigerian state but is also responsible for the global perception that afflicts anyone called a Nigerian [6]. Osaghae [7] reveals that, for effective leadership to be attained, it is important to place the requisite institutional correlates that are consonant with democracy, rule of law and accountability and capable of restraining the tendencies towards the personalisation of political power. Literature on Nigeria's leadership challenges from the lens of 1 Kings 3:3-14 is scanty. This study intends to fill this gap.

Using the narrative analysis, first this article carries out an exegesis of 1 Kings 3:3-14. Second, it brings out important themes in the pericope. Third, this study explores leadership challenges in Nigeria and thereafter an application of 1 Kings 3:3-14 to the Nigeria context is made.

\section{The Context of 1 Kings 3:3-14}

The context is the champion when determining the interpretation of a word or passage [8]. The book of 1 Kings was written during the Babylonian exile of Israel. It records the history of Israel's monarchy from the beginning of Solomon's reign in about 970 B.C. to the fall of Jerusalem in 586 B.C [9]. From the beginning, 1 Kings was written as one book with 2 Kings. During the time of Solomon, Israel was at the peak of its power. David had conquered the neighboring peoples who were hostile to Israel. Egypt on the southern border was an ally, and Solomon married Pharaoh's daughter in order to strengthen this alliance with neighbouring nations (1 Kings 3:1) [10]

To the north, Hiram of Tyre was also a friend, and there was peace with Syria and the northeastern nations [11]. Solomon reigned between 973 B.C. - 933 B.C [11]. Friedman and Friedman [12] Tisdell and Svizzero [13] and Hopkins [14] reveal that in displaying political and administrative wisdom, Solomon took full advantage of the unparalleled opportunity for economic growth and development which is seen in his bilateral agreement with the Hiram of Tyre. Tyre supplied artisans for the bronze-work in the Jerusalem temple and also assisted Solomon with the building of the Red Sea merchant fleet in Israel and supplied crew for these ships [15]. Furthermore, there was peace during the reign of Solomon which was a rare feat attained by his predecessors.

Literally, 1 Kings 3:3-14 has the narrative genre. Its setting was in Jerusalem, and the major character was Solomon. David died and Solomon was the leader in charge of Israel. Solomon knew the ways that David worked and achieved great success during his leading of Israel. This made him go to Gibeon, where his father also went, to sacrifice unto God. He offered a burnt offering of thanksgiving and prayer to God. His show of gratitude to God made his reign to be peaceful. He was able to divide Israel into twelve districts for effective management [16]. 
God appeared to him and told him to ask anything. Solomon began to remind God of how he had helped his predecessor, David. This help according to Solomon helped David to rule effectively. Solomon reminded God of David's righteousness and uprightness in leading the people of Israel. Solomon was sincere in telling God that he was a child and needed guidance. He sought guidance from God (the same guidance that God gave to David that enabled him to succeed effectively). He further built a temple for God. This shows his understanding of architectural design [17]. The temple Solomon built gave the Israelites their lost identity with Yahweh. Solomon's temple was a very iconic temple in Jerusalem which was erected in the 966 BC on the Temple Mount of Jerusalem by King Solomon and was the first fixed building of a temple and the most important sanctuary of the Jews, which kept the Ark of the Covenant and represented the House of God amongst humankind [18].

\section{Close Reading of the Text}

Close reading, also known as close textual analysis, investigates the relationship between the internal workings of discourse in order to discover what makes a particular text function persuasively [19]. The pericope reveals four structures. The first part is v. 3, the second part is vv.4-9, the third part is vv.10-13 and the last part is v.14.

Solomon continued in the footsteps of his predecessor (v.3). He made friendship with the good friends of his predecessor. He followed David's developmental strides and strategies. This structure could be termed "keeping to promises and developments of a predecessor". Solomon went to make a sacrifice to the God of David (vv.4-9). He went with gifts to prove his preparedness for good advice. This part could be called "keeping good advisers friends". God, who worked with David, was happy that Solomon came to him to seek advice and help from him (vv.10-13). God gave him knowledge, wisdom, understanding, riches and honour. This part could be termed "functions of good advisers". The last part is an epilogue that contains those things that would sustain Solomon's leadership (v.14). They include Solomon commitment to God's statutes just as David. This structure could be called "maintaining the goodwill of the people".

\subsection{Keeping to Promises and Developmental Strides of a Predecessor (v.3)}

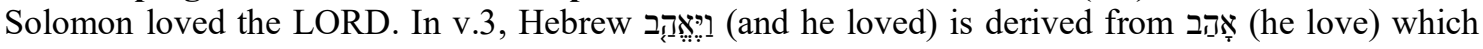
means that Solomon loved the things that David his predecessor loved. David worked in the statutes of David, and so did Solomon. Solomon truly loved God and made his conscience of walking in his

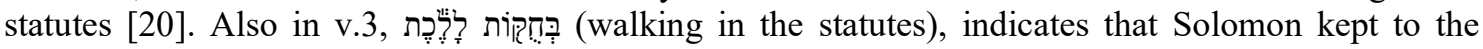

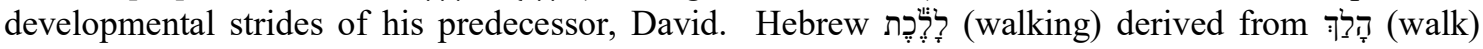
reveals that Solomon followed continually the good steps of David. Solomon was for the most part a king committed to God.

\subsection{Keeping Good Advisers as Friends (vv.4-9)}

Solomon went God, who was David's pillar of effective leadership. This was to seek the favour of God for a peaceful reign and to avoid making unnecessary mistakes. God listened to Solomon due to

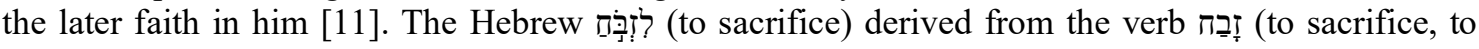
offer, to worship) shows that Solomon came to sacrifice and pray to God. Solomon went to sacrifice at Gibeon. The tabernacle at Gibeon was the same tabernacle that the children of Israel, under Moses leadership constructed in the wilderness many years previously [21]. In v. 5, God asks Solomon

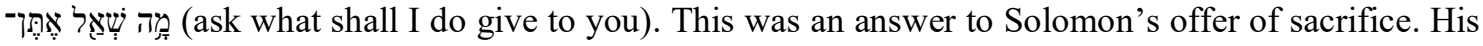
offer of sacrifice showed his humility of Solomon. Hebrew שָׁ (ask) shows that God was interested in the government of Solomon. and also to request petition. Before God said 'ask', Solomon's ways satisfied and convinced him.

In v.6, Solomon recalled those things that God did for his predecessor, David. He told God that he

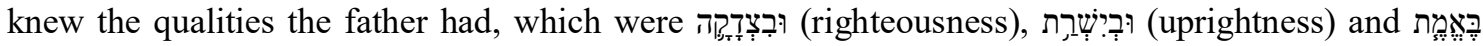
(truth). Solomon reminded God of these qualities because he needed. In v.7, Solomon showed

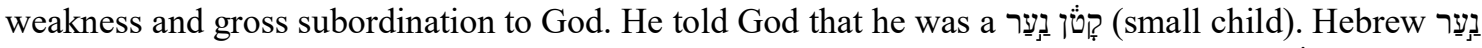
could mean a child or a servant who was at the mercy of the chief. Using the adjective the boy indicates Solomon's level of humility and plea for help.

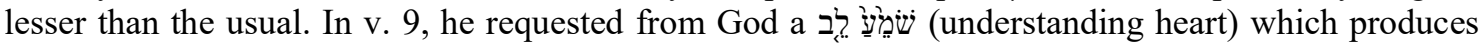
righteousness, uprightness and truth. This בשign was to help Solomon hear, listen, diligently comprehend, and truly obey God in his leadership of Israel. 


\subsection{Functions of Good Advisers (vv.10-13)}

Traditionally, a good mentor or adviser is happy when their mentees are succeeding. In v.10, God was

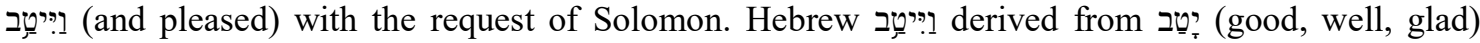
means that Solomon's request was good and accommodated the interest of God. Solomon loved truth, righteousness and uprightness, which are the hallmarks of God's concern for Israelite leaders. In v.14, God gave Solomon other things he had not requested - riches and honour. Walsh [22] states that Yahweh's response has three elements: firstly, Solomon is praised for not requesting for long life, riches, or domination over others. Secondly, he is given a wise and discerning mind. Thirdly, he

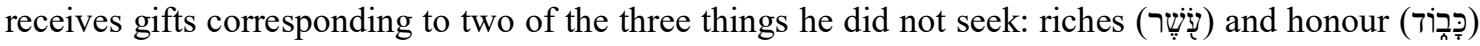
above kings (v.13). What God gave to Solomon are core parts of administration which include an understanding heart, riches, honour above all kings.

\subsection{Maintaining the Goodwill of the People (vv.14)}

In v.14, God reminded Solomon to rule with righteousness, truth and uprightness. He also told him that these were the conditions that would ensure his continuous patronage of Solomon. God promised

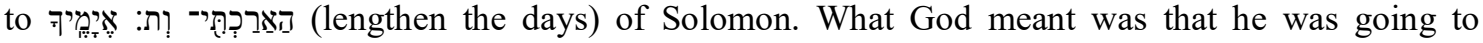
prolong and extend the tenure of Solomon as Israel's King. After his meeting with God, Solomon's reign was a "period of peace, in addition to the steady growth of his wealth and prosperity, foreign trade and building" [23].

The exegesis of the pericope reveals that Solomon kept to the positive footprints of his predecessor. He also maintained those vital leadership virtues such as truth, righteousness and uprightness. At this juncture, there is the need to review leadership challenges in Nigeria and the theological implications of 1 Kings 3:3-14.

\subsection{Leadership Challenges in Nigeria}

Leadership refers to all the processes involved in the making, interpreting and enforcing the laws of the state. Nigeria is a country of over two hundred million people, with six geopolitical zones, viz: north-east, north-west, north-central, south-west, south-east, and south-south. The first three zones are mainly Muslim territories, while the last three are mainly Christian territories.

Before anyone gets into political office, elections are made. Elections are preceded by campaigns. During campaigns, aspirants make many promises about what they have in mind to help the citizens with. Most times these promises are fake, that is why many political leaders in Nigeria do not deliver on their electoral promises or live up to expectations [24]. Walter [25] lamented that corruption is responsible in a large measure for broken promises, the dashed hopes and shallow dreams that have characterized the lives of most Nigerians in the past few decades. Political leaders mention how they will reduce poverty, reduce unemployment and also build infrastructures such as electricity, pipeborne water and also hospitals.

Political leaders acquaint themselves with sycophants and godfathers. Erik [26] laments that "sycophants are always driven by greed and selfishness". He further lamented that sycophants and godfathers are driven by convulsive rapaciousness and are egocentric boot-lickers who hide under the cloak of patriotism and nationalism to pursue a purely self-serving agenda. These sets of individuals make the leader to engage in corruption, narcissism and hubris.

In Nigeria, political leadership has been the bane of Nigeria's growth and development. Leaders are very anxious to get into positions to siphon state monies for their selfish aims and objectives. This is why Anjorin [27] sketches that it is sickening looking at how politicians treat Nigerians who voted for them, and more baffling how voters keep mute and refuse to demand accountability for stewardship from their leaders. Nigerian leaders choose to play around, without thought for their people's welfare and societal progress. They, their cronies and their family members' siphoned state treasury for their personal use.

\subsection{Causes of Challenges in Nigeria's Leadership}

The causes of leadership challenges in Nigeria cannot be overemphasized. First, the high cost of party tickets, godfatherism, and costly electioneering campaigns. Political aspirants pay a lot to get both party ticket and also nomination by delegates. Furthermore, most political aspirants have political godfathers who spend a lot during electioneering campaigns to ensure that their political son gets into 
office. When the political aspirant finally gets the leadership position, he steals public funds in order to recover what he had spent and also settles his godfathers financially.

Second, people are unprepared for leadership positions. Most leaders do not prepare themselves for what leadership position needs. What they are concerned about is how to clinch the leadership position and become rich. This makes them not to be able to do anything for the citizens. For instance, a former governor, and also the current minister of transportation, Rotimi Amaechi, revealed unemployment made him to enter politics [28]. This shows that Nigerian leaders are not prepared for leadership, which made them lack management leadership. Management leadership provides the opportunity for citizen's skills to be utilised and it provides the resources to be exploited [29].

Third, successors blackmail their predecessors. When a predecessor takes over a leadership seat, he tries everything to paint the successor in the bad light. He does not find the good things that the predecessor had done so as to continue on it.

Four, there is lack of dialogue and power distance between the ruled and the rulers. The citizens are so much afraid of their rulers. The leaders who were supposed to be chief servants have made the citizens the chief servants. The citizens do not have the needed political education to know their right and privileges. Nigerians hold political leaders in too high esteem, which is the reason political leaders are authoritarian in decision making and governance. Political education is among the citizens is lacking [29].

\subsection{Impacts of Nigeria's Leadership Challenges}

First, there is an increase in poverty all over Nigeria. Many Nigerians cannot feed, cloth, or house themselves due to poverty. Muhammad [30] reveals that "at the root of poverty lies the deprivation of people's access to basic necessities such as food, healthcare and sanitation, education and assets". Most Nigerian's due to ineffective leadership cannot feed, go to school or pay for the escalating health care fees.

Second, youths see leadership as a place to amass ill-gotten wealth. This is the impact of the high level of stealing of public money by those in leadership positions. Unfortunately, most of these youths are children, friends, and also sub-ordinates of most of the corrupt leaders. There is the tendency that the youths may be more corrupt than the present political leaders in Nigeria [31], because they can see politics as a platform for making fast wealth. The youths are scrambling for political power, just to stay relevant and get access to the commonwealth that politicians have been sharing among themselves [32].

Third, Nigeria has continued to witness underdevelopment in all sectors. There are ill-equipped hospitals [33], ill-equipped and dilapidated schools [34], bad roads, and ill-equipped information and communication technology labs in institutions of research. There is the lack of basic amenities, lack of access to education, and also lack of housing.

Four, there has been an increase in social crimes in Nigeria. This can be seen in the high level of prostitution, drug trafficking, child trafficking and kidnapping. Ogoma [35] puts forward that poor leadership and corruption are the cause of these immoralities in Nigeria. Nigerians have decided to take their destinies into their hands, by deciding to do anything to survive.

Five, poor political leadership has led to conflicts in Nigeria. Political leaders favour their ethnic, tribal and religious group. There has increased the level of suspicion and conflict among Nigerians. One ethnic group suspects the other ethnic groups of trying to dominate them. Christian political leaders are suspected by the Muslims of favouring the Christian community while Muslim political leaders are suspected by the Christians of favouring the Muslim community in Nigeria. Eyitayo concluded it is bad leadership that leads to depression and conflict [36].

Six, it has increased suicide in Nigeria. People are tired of living a life of suffering with no hope in sight. The shame of having no house to live, no food to eat, and no job have forced many Nigerians to take their lives. They see suicide as the best way to escape the rot in Nigeria's political leadership. Nigeria is ranked 15th in the world and top in Africa for its suicide rate [37].

\subsection{Theological Implications of 1 Kings 3:3-14 to the Nigerian Context}

Leaders are called upon to imbibe the good virtues of their predecessor. Solomon started by observing where his predecessor had made marks. He discovered it. Solomon worked in the ways of his father, David (his predecessor). Furthermore, David loved the Lord and Solomon also loved the Lord. Solomon himself followed the law of the Lord in all respects [9]. This shows he kept to the standards 
upheld by his predecessor. Bringing this development to Nigeria's political field, it is sad to note that successors paint their predecessors in a very bad light. They do not see anything good in what their predecessor had done. This has made Nigeria to continue to move farther backwards rather than forward. In Nigeria, a leader starts a good project, and when he is unable to finish it before the end of his tenure, the successor takes over leadership and abandons that project. Successors try to paint everything about their predecessors in a bad light.

Leaders are enjoined to keep good company to ensure success. Solomon was close to God, who was the good adviser that David had. He knew that it was God's good pieces of advice that helped David's success in his leadership. He went to sacrifice to God at Gibeon. He went with so many burnt offerings to prove his submission to the God's direction. In Gibeon the Lord appeared to Solomon, and asked him what he wanted. Solomon reminded God of some virtues in his predecessor that he needed for his success. He mentioned truth, righteousness, and uprightness. Solomon further showed humility to God by telling God that he knew nothing on leadership. He said, "I know not how to go out or come in". He asked for an understanding heart which encompasses righteousness, truth and uprightness. In Nigeria, it is unfortunate that political leaders do not keep good advisers as close associates. They keep sycophants and political godfathers around them. This is the reason that monies meant for development are coerced into their private pockets and that of their godfathers. What is practised is the system of table manners: "do not talk while eating". They share the state funds and nobody is expected to talk. After their tenure, they succeeded in achieving anything.

Good mentors are happy when their mentees are following their good steps. God was very happy with the decision of Solomon. God discovered that Solomon was dedicated with his ambition of leading effectively. God told Solomon that he was happy that he did not ask for the head of his predecessors (his enemies). God promised to give him wisdom and understanding and also riches and honour. Looking at Nigeria's political leaders, one begins to wonder what went wrong. The special advisers around political leaders are just there for their political gain. The special advisers are the godfathers who coerced the leader into using state funds as their personal money-making machine. These godfathers are "political sponsors, who use money and influence to win support for their preferred candidates. Their "godsons", it is believed, are not always selected for their political acumen, but rather on their ability to repay and enrich their godfather" [38].

God reminded Solomon that for Solomon to enjoy his support, he must keep to his statutes. God also told him that this was the secret of David's successful leadership. In Nigeria, the friends, advisers, and godfathers of political officeholders in Nigeria threaten these political leaders of expulsion from their political seat if they play to their whims and caprices. The reward for the godfather puts the leader in a dependent and precarious position [39]. Godfathers remind their godsons of the implications of not abandoning their sole interests.

\section{Defining the Roadmaps}

The following recommendations would help to solve the leadership challenges in Nigeria in the light of 1 Kings 3:3-14.

1. Successors should try to focus attention on the strength of their predecessors, just as Solomon did. Any good or noble ideal of the predecessor should be encouraged in order to attain the needed development.

2. People in leadership positions should try to be close to those persons with sound judgment. Solomon brought himself closer to God. This made his leadership to be sound and peaceful. Nigerian political leaders should also bring into their team those persons with special skills who had worked with his predecessor.

3. Elder statesmen should not see themselves as a tool for siphoning public fund. This tactic of elder statesmen making themselves political-godfathers and threatening a leader does not aid development in Nigeria. Instead, godfathers should put in their ideas, actions and other inputs needed for success by the leader.

4. Those persons close to the leader must be able to tell him that any anti-citizen policies and actions will not go down well with the society. God told Solomon the implications of abandoning the good footsteps of David. This made Solomon to be focussed. This will make the leader to sit up knowing that he would not like to be a failure to the citizens, himself and his advisers. 
5. There is the need for leaders to know that any bad policy or action they carry out will be a sting to their name even after they may have left their political office. There is the need for them to practice management leadership void of corruption.

\section{Conclusion}

1 Kings 3:3-14 reveals that for leadership to be successful there is the need for successors to carry out the good policies and projects of their predecessors rather than resorting to blackmail to score cheap political points. Leaders should also be wary of sycophants and godfathers who are selfish in their contributions to society development. Solomon took over the good policies of his father David, and also imbibed those virtues (truth, righteousness, uprightness) that aided David in achieving success in his leadership. This is worthy of emulation by Nigerian leaders. Political leaders in Nigeria should not condemn all the policies of their predecessors. Furthermore, in order to achieve the needed development in Nigeria, there is a need for the leader to be closer to good advisers rather than allowing sycophants and godfathers to coerce them into betraying their people.

\section{References}

[1] B. Adebayo, "Nigeria overtakes India in extreme poverty ranking," June 2018. [Online]. Available: https://edition.cnn.com/2018/06/26/africa/nigeria-overtakes-india-extreme-povertyintl/index.html. [Accessed: 2020].

[2] C. Achebe, The trouble with Nigeria, Heinemann: New Hampshire, 1983.

[3] O. Olaniyi, "We will retrieve N96bn stolen during Ajimobi's tenure - Makinde", The Punch, vol. 1, August 2020.

[4] E. C. Ukhun, "Godfatherism, the Scourge of Democracy in Nigeria," Essence Interdisciplinary International Journal, vol. 1, 2004.

[5] Anetoh, B. Chike, and V. G. Onwudinjo. "Emigration and the problem of brain drain in Nigeria: a philosophical evaluation," Journal of African Studies and Sustainable Development 3 , no. 1, 2020.

[6] V. U. Onyemauwa, "Servant Leadership and Effective Implementation of Public Policy: Catalyst for Sustainable Development in Nigeria," South Eastern Journal of Research and Sustainable Development (SEJRSD), vol. 2, no. 1, pp. 228-250, 2019.

[7] E. Osaghae, "The limits of charismatic authority and the challenges of leadership in Nigeria," Journal of Contemporary African Studies, vol. 28, no. 4, pp. 407, 2010.

[8] J. S. Duvall, and J. D. Hays, Grasping God's Word: A hands-on approach to reading, interpreting, and applying the Bible, 3 Ed. Zondervan: Grand Rapids, 2012.

[9] T. Hale and S. Thorson, 1 Kings the applied Old Testament commentary. Colorado: David C. Cook Springs, 2007.

[10] M. Gotom, 1 and 2 Kings', African Bible Commentary. Nairobi: WordAlive Publishers, 2006,

[11] M. Gotom, 1 and 2 Kings', ed. Tokunboh Adeyemo, Africa Bible Commentary. Nairobi: WordAlive Publishers, 2006.

[12] H. H. Friedman, and L. W. Friedman, "What Went Wrong? Lessons in Leadership from Solomon, the Bible's Wisest and Worst Ruler" Journal of Values-Based Leadership, vol. 12, no. 1, pp. 1-20, 2018.

[13] C. Tisdell, and S. Svizzero, "Economic Theory, Phoenician Pre-coinage External Trade, Changes in the Economic Surplus and its Appropriation - An initial Perspective," November 2019. [Online]. Available: https://hal.archives-ouvertes.fr/hal-02274893/document. [Accessed: 2020].

[14] D. C. Hopkins, Solomon and Economic Reconstruction, in the Age of Solomon, ed. L. K. Handy. Leiden: Brill, 1977.

[15] A. Mark, "How reluctant achievers become confident achievers for God," August 2015. [Online]. Available: http://www.markalanwilliams.net/2015/08/04/how-reluctant-leadersbecome-confident-achievers-for-god/. [Accessed: 2020].

[16] W. Benke, L. E. Benke, E. S. Robert and L. L. David, Church Wake-Up Call: A Ministries Management Approach That is Purpose. New York: Routledge, 2014.

[17] Y. Yadin, "Solomon's City Wall and Gate at Gezer," Israel Exploration Journal, vol. 8, no. 1, 1958. 
[18] T. P. Kersten, F. Tschirschwitz, M. Lindstaedt, and S. Deggim, "The historic wooden model of Solomon's Temple," Journal of Cultural Heritage Management and Sustainable Development, vol. 2, 2018

[19] M. Allen, Close Reading, the SAGE Encyclopedia of Communication Research Methods. CA: SAGE Publications, 2007.

[20] M. Henry, 1 Kings 3, Matthew Henry's Commentary. Peabody: Hendrickson Publishers, 2006.

[21] A.E. Hill, 1 \& 2 Chronicles' NIV Application Commentary. Zondervan: Grand Rapids Michigan, 2003.

[22] J. T. Walsh, "The Characterization of Solomon in First Kings 1-5," Catholic Biblical Quarterly, pp. 57, 1995.

[23] S. J. McKenzie, Dictionary of the Bible. London: Geoffrey Chapman, 1965.

[24] G. Salau, "CAN leader reveals why politicians don't keep promises," The Guardian, pp. 1, 2018.

[25] L. Walter, "Nigeria: The African giant - the continent's largest and most populous country is also a country in transition," Ebony, pp. 45, 1990.

[26] Erik, "Politics of sycophancy in Nigeria," Blueprint, pp.1, 2017.

[27] O. Anjorin, "Sycophantic fangs in our society," The Nation, 2018.

[28] T. Abioye, and T. Ige, "Unemployment drove me into politics - Rotimi Amaechi", The Punch, pp.1, 2020.

[29] G. Ehiaghe, "Nigeria is suffering because of poor leadership," The Guardian, pp. 1, 2018.

[30] A. S. Muhammad, "Three things Nigeria must do to end extreme poverty," March 2019. [Online]. Available: from https://www.weforum.org/agenda/2019/03/90-million-nigerians-livein-extreme-poverty-here-are-3-ways-to-bring-them-out/. [Accessed: 2020].

[31] W. B. Adisa, "The travails and challenges of a post-military state on Nigerian youth," International Journal of Sociology and Anthropology, vol. 5, no. 7, pp. 229, 2013.

[32] T. Fasua, "The Greatest Conspiracy against Nigeria Youths," 2018. [Online]. Available: https://www.proshareng.com/news/Nigeria\%20Economy/The-Greatest-Conspiracy-AgainstNigeria-Youths/42673. [Accessed: 2020].

[33] O. Menizibeya, "Welcome," J Pharm Bioallied Sci, vol. 3, no. 4, pp. 470-478. Oct 2011.

[34] A. Soyinkoa, and K. Mohammed, "Why Nigeria's educational system is in crisis - and how to fix it," 2020. [Online]. Available: https://www.bbc.co.uk/programmes/articles/3RbFXDdBw3g 0HQG0fpyD0xF/why-nigerias-educational-system-is-in-crisis-and-how-to-fix-it. [Accessed: 2020].

[35] D. E. Ogoma, "Leadership, Corruption and Governance in Nigeria," International Journal of Politics and Good Governance, vol. 5, no. 3, 2014.

[36] O. Eyitayo, "Nigeria: Bad Leadership, the Bane of National Development," Daily Independent, pp. 1, 21 July 2011.

[37] J. Motunrayo, "Nigeria ranked 15th in the world for suicide but Lesotho tops African list," Feb 2019. [Online]. Available: https://africacheck.org/reports/nigeria-ranked-15th-in-the-world-forsuicide-but-lesotho-tops-african-list/. [Accessed: 2020].

[38] M. Jones, "Nigeria election, How 'godfathers' influence politics," Feb 2019. [Online]. Available: https://www.bbc.com/news/world-africa-47089372. [Accessed: 2020].

[39] O. Olarinmoye, "Godfathers, political parties and electoral corruption in Nigeria," African Journal of Political Science and International Relations, vol. 2, no. 4, pp. 67, 2008. 